\title{
Effects of propofol on human cholangiocarcinoma and the associated mechanisms
}

\author{
ZHUO ZHANG, MINGCUI ZANG, SHUANG WANG and CHUNLI WANG
}

Department of Hepatobiliary and Pancreas Surgery, The First Hospital of Jilin University, Changchun, Jilin 130021, P.R. China

Received May 7, 2018; Accepted July 26, 2018

DOI: $10.3892 /$ etm.2018.6908

\begin{abstract}
Cholangiocarcinoma (CCA) is the most common type of biliary duct malignancy. Propofol is a fast-acting intravenous anesthetic, which also exerts an anti-cancer effect. The aim of the current study was to explore the effects of propofol on human CCA and the associated mechanisms in vitro. The results indicated that as concentration $(0,1,5$ and $10 \mu \mathrm{g} / \mathrm{ml})$ of propofol and treatment time $(24,48$ and $72 \mathrm{~h})$ increased, the cell inhibition rate of human CCA QBC939 cells increased. Furthermore, treatment with various concentrations of propofol for $48 \mathrm{~h}$ resulted in a decrease in migration and invasion capacity in QBC939 cells. Propofol also induced the apoptosis of QBC939 cells and cell cycle arrest in G1 phase. Propofol treatment increased the expression level of Bax and decreased that of $\mathrm{Bcl}-2$. In addition, the effects of propofol on gene expression were evaluated, including Wnt $3 \alpha, \beta$-catenin, Snail1 and c-myc in the $\mathrm{Wnt} / \beta$-catenin signaling pathway. It was identified that as the concentration of propofol increased, the expression of these genes decreased. In conclusion, the current results indicate that propofol is a promising therapeutic agent for the treatment of CCA.
\end{abstract}

\section{Introduction}

At present, cholangiocarcinoma (CCA) is the most prevalent bile duct malignancy in the clinic and is a fatal malignancy originating from biliary epithelial cells $(1,2)$. In recent decades, the incidence of CCA has increased $(3,4)$. Surgery is the preferred treatment for CCA, but it is also carries risks and there are numerous complications following surgery (5). Therefore, postoperative care and rehabilitation training for patients with postoperative CCA is very important. Currently, the prognosis of patients with CCA remains unsatisfactory, with a 5-year survival rate of $\sim 5 \%$ (6). In addition, CCA is generally resistant to chemotherapeutic drugs, and is prone

Correspondence to: Dr Chunli Wang, Department of Hepatobiliary and Pancreas Surgery, The First Hospital of Jilin University, 71 Xinmin Street, Changchun, Jilin 130021, P.R. China E-mail: wangcl201805@163.com

Key words: propofol, QBC939 cells, Wnt/ $\beta$-catenin signaling pathway to relapse and metastasis (7). Therefore, it is of great clinical significance to identify highly effective therapeutic drugs with minimal side effects and to clarify the mechanism of action, in order to improve the therapeutic effect and prolong the survival of patients with CCA.

Propofol (2, 6-diisopropylphenyl), an alkyl acid, is a fast-acting intravenous anesthetic. It is a widely used drug for induction and maintenance of anesthesia in the clinic (8). Propofol injection has the characteristics of rapid distribution (half-life of 2-4 min) and rapid elimination (half-life of 30-60 min) (9). Numerous studies have demonstrated the superiority of propofol over volatile agents, because propofol does not suppress the immune system in a cancerous environment (10-14). In recent decades, numerous studies have demonstrated that propofol has a variety of other effects, including possible anti-cancer actions (15-18). However, to the best of our knowledge, the effect and mechanism of propofol on CCA cells remains unclear. Therefore, the current study aimed to investigate the effect and molecular mechanism of propofol on CCA cancer in vitro.

\section{Materials and methods}

Materials. The human CCA cell line QBC939 was obtained from American Type Culture Collection (Manassas, VA, USA). Dulbecco's modified Eagle medium (DMEM) and fetal bovine serum (FBS) were purchased from Gibco (Thermo Fisher Scientific, Inc., Waltham, MA, USA). All primary antibodies [anti- $\beta$-actin (cat. no. 4970), anti-CyclinE (cat. no. 20808), anti-Bax (cat. no. 5023), anti-Bcl-2 (cat. no. 4223), anti-Wnt3a (cat. no. 2721), anti-Snaill (cat. no. 3879), anti-c-myc (cat. no. 13987) and anti- $\beta$-catenin (cat. no. 8480)] were acquired from Cell Signaling Technology, Inc. (Danvers, MA, USA).

Cell culture and treatment. Human CCA QBC939 cells were cultured in DMEM supplemented with $10 \% \mathrm{FBS}$ and $1 \%$ penicillin/streptomycin. The cells were incubated in a humidified incubator at $37^{\circ} \mathrm{C}$ with $5 \% \mathrm{CO}_{2}$. Propofol was dissolved in dimethyl sulfoxide (DMSO) and stored at $-20^{\circ} \mathrm{C}$. QBC939 cells were treated with various concentrations of propofol $(0$, $1,5$ or $10 \mu \mathrm{g} / \mathrm{ml})$ for 24,48 or $72 \mathrm{~h}$ at $37^{\circ} \mathrm{C}(19,20)$. Then, the cells were subjected to assays as described below.

MTT assay. Cells were collected at logarithmic phase, inoculated in a 96-well plate with $1 \times 10^{4}$ cells/well and incubated at 
$37^{\circ} \mathrm{C}$ with $5 \% \mathrm{CO}_{2}$ for $12 \mathrm{~h}$. Then, the cells were treated with various concentrations of propofol $(0,1,5$ or $10 \mu \mathrm{g} / \mathrm{ml})$ for 24,48 or $72 \mathrm{~h}$ at $37^{\circ} \mathrm{C}$. Subsequently, MTT $(20 \mu \mathrm{l} ; 5 \mathrm{mg} / \mathrm{ml})$ was added to each well, and the cells were incubated for a further $4 \mathrm{~h}$. The formazan crystals were dissolved in $150 \mu \mathrm{l}$ DMSO and stirred slowly for $10 \mathrm{~min}$. The optical density (OD) of each sample was determined at the wavelength of $570 \mathrm{~mm}$ with an immunoassay analyzer. The cell inhibition rate $=(1-O D$ value of treatment group/OD value of control $)$ $\mathrm{x} 100 \%$. All experiments were performed in triplicate and repeated three times.

Western blotting. QBC939 cells were treated with various concentrations of propofol $(0,1,5$ or $10 \mu \mathrm{g} / \mathrm{ml})$ for $48 \mathrm{~h}$ at $37^{\circ} \mathrm{C}$. Then the cells were washed with PBS three times and lysed on ice in radioimmunoprecipitation buffer (cat. no. P0013B; Beyotime Institute of Biotechnology, Nanjing, China) with $1 \mathrm{mM}$ PMSF for $30 \mathrm{~min}$ at $4^{\circ} \mathrm{C}$. Protein was collected and stored $-20^{\circ} \mathrm{C}$. Bicinchoninic protein assay kit (Pierce; Thermo Fisher Scientific, Inc.) was used to detect protein concentration. Equal amounts of protein $(30 \mu \mathrm{g} /$ lane $)$ were separated by $10 \%$ SDS-PAGE and transferred to polyvinylidene difluoride membranes. Then, the membrane was blocked at room temperature for $2 \mathrm{~h}$ with 5\% skimmed milk in PBS with $0.1 \%$ Tween-20 (PBST) and incubated with primary antibodies ( $\beta$-actin, CyclinE, Bcl-2, Bax, Wnt3a, $\beta$-catenin, Snail1 and c-myc; all 1:1,000; Cell Signaling Technology, Inc.) overnight at $4^{\circ} \mathrm{C}$. The following day, the membrane was washed four times in 1X PBST (10 min/wash) and incubated with anti-rabbit immunoglobulin $\mathrm{G}$ horseradish peroxidase-coupled secondary antibodies (cat. no. 7074; 1:1,000; Cell Signaling Technology, Inc.) for $2 \mathrm{~h}$ at room temperature. Proteins were detected using SignalFire $^{\mathrm{TM}}$ Plus ECL Reagent (cat. no. 12630; Cell Signaling Technology, Inc.) and imaged. $\beta$-actin was used as an internal control.

Transwell assay. To investigate the effects of propofol on QBC939 cell migration and invasion, a 24-well Transwell plate $(8-\mu \mathrm{m}$ pore size) was used. The chamber inserts were coated with or without $200 \mathrm{mg} / \mathrm{ml}$ of BD Matrigel ${ }^{\mathrm{TM}}$ Matrix (BD Biosciences, Franklin Lakes, NJ, USA) for the invasion and migration assay, respectively. Logarithmic phase QBC939 cells were inoculated into 6 -well plates $\left(1 \times 10^{4}\right.$ cells/well $)$ and placed in a constant temperature incubator for routine culture. When the cells reached $70-80 \%$ confluence, they were treated with various concentrations of propofol for $48 \mathrm{~h}$. Then, $100 \mu \mathrm{l}$ DMEM containing 10\% FBS was added to the upper chamber for $1 \mathrm{~h}$. Subsequently, the cells were digested with $0.25 \%$ trypsin and resuspended in DMEM to prepare a single cell suspension. The cell density was adjusted to $10^{6}$ cells $/ \mathrm{ml}$. DMEM $(0.5 \mathrm{ml})$ containing $10 \%$ FBS was added to the lower chamber, and $100 \mu \mathrm{l}$ cell suspension was added to the upper chamber of each insert. The plates were cultured at $37^{\circ} \mathrm{C}$ with $5 \% \mathrm{CO}_{2}$ for $24 \mathrm{~h}$. Then, cells that had not migrated or invaded from the upper chamber to the lower chamber were gently wiped away with a clean cotton swab. The cells on the lower chamber were stained with $0.5 \mathrm{ml} 0.1 \%$ crystal violet at room temperature for $20 \mathrm{~min}$. Five fields of view were observed for each chamber by a light microscope and the mean value was calculated.
RNA isolation and reverse transcription-quantitative polymerase chain reaction ( $R T-q P C R)$. Total RNA was extracted from QBC939 cells using TRIzol reagent (Invitrogen; Thermo Fisher Scientific, Inc.) according to the manufacturer's protocol. The RNA concentration was detected using NanoDrop 2000 (Thermo Fisher Scientific, Inc.). Total RNA was reverse transcribed into cDNAs using the PrimeScript RT Reagent kit (Takara Bio, Inc., Otsu, Japan) according to the manufacturer's protocol. qPCR was performed using QuantiFast SYBR Green PCR kit (Qiagen, Inc., Valencia, CA, USA) and a CFX Connect Real-Time system (Bio-Rad Laboratories, Inc., Hercules, CA, USA). Amplification conditions were as follows: $10 \mathrm{~min}$ at $95^{\circ} \mathrm{C}$, followed by 35 cycles of $15 \mathrm{sec}$ at $95^{\circ} \mathrm{C}$ and $40 \mathrm{sec}$ at $55^{\circ} \mathrm{C}$. The primer sequences used for RT-qPCR were listed in Table I. Relative gene expression was analyzed using the $2^{-\Delta \Delta C q}$ method (21).

Flow cytometry analysis. QBC939 cells were collected in logarithmic growth phase, and the cell suspension density was adjusted and inoculated into 6 -well plates at $1 \times 10^{5}$ cells/well. Subsequently, cells were treated with various concentrations of propofol for $48 \mathrm{~h}$. Then, the cells were fixed with $70 \%$ methanol at $-20^{\circ} \mathrm{C}$ overnight, washed with PBS twice, stained with propidium iodide (PI; cat. no. 4087; Cell Signaling Technology, Inc.) and incubated at $4^{\circ} \mathrm{C}$ for $30 \mathrm{~min}$ in the dark. Flow cytometry was performed to detect cell-cycle distribution. For detection of cell apoptosis, cells were stained with Annexin V and PI for $15 \mathrm{~min}$ at room temperature in the dark prior to flow cytometry. Data were analyzed using WinMDI (version 2.5; Purdue University Cytometry Laboratories, West Lafayette, IN, USA).

Statistical analysis. All quantitative data are presented as the mean \pm standard deviation. All experiments were repeated three times. Differences between multiple groups were compared by one-way analysis of variance followed by Tukey's test, and differences between two groups were compared by Student's t-test. GraphPad Prism 6 software (GraphPad Software, Inc., La Jolla, CA, USA) was used to perform statistical analysis. $\mathrm{P}<0.05$ was considered to indicate a statistically significant difference.

\section{Results}

Propofol inhibits QBC939 cell proliferation. In order to study the anti-tumor effect of propofol on human CCA cells, an MTT assay was performed. Following treatment with various concentrations of propofol for 24,48 or $72 \mathrm{~h}$, respectively, inhibition of proliferation appeared to increase as concentration of propofol in QBC939 cells and the duration of the incubation increased (Fig. 1).

Propofol inhibits migration and invasion capacity in QBC939 cells. The effects of propofol on migration and invasion of QBC939 cells were examined by Transwell assay. The results indicated that migration and invasion of cells decreased gradually with increased concentrations of propofol compared with the control (Fig. 2). Doses of 1, 5 and $10 \mu \mathrm{g} / \mathrm{ml}$ significantly decreased migration and invasion compared with the $0 \mu \mathrm{g} / \mathrm{ml}$ group. 
Table I. Primer sequences for polymerase chain reaction.

Primer $\left(5^{\prime}-3^{\prime}\right)$

\begin{tabular}{lll}
\cline { 2 - 3 } Gene & \multicolumn{1}{c}{ Forward } & \multicolumn{1}{c}{ Reverse } \\
\hline Bcl-2 & TTGGATCAGGGAGTTGGAAG & TGTCCCTACCAACCAGAAGG \\
Bax & CGTCCACCAAGAAGCTGAGCG & CGTCCACCAAGAAGCTGAGCG \\
Cyclin E & AGCCAGCCTTGGGACAATAAT & GAGCCTCTGGATGGTGCAAT \\
Wnt3a & GGCTCCTCTCGGATACCTCT & GGGCATGATCTCCACGTAG \\
$\beta$-catenin & AACAGGGTCTGGGACATTAGTC & CGAAAGCCAATCAAACACAAAC \\
Snail 1 & GGTTCTTCTGCGCTACTGCTG & GTCGTAGGGCTGCTGGAAGG \\
c-myc & CATCAGCACAACTACGCAGC & GCTGGTGCATTTTCGGTTGT \\
GAPDH & CTTTGGTATCGTGGAAGGACTC & GTAGAGGCAGGGATGATGTTCT
\end{tabular}

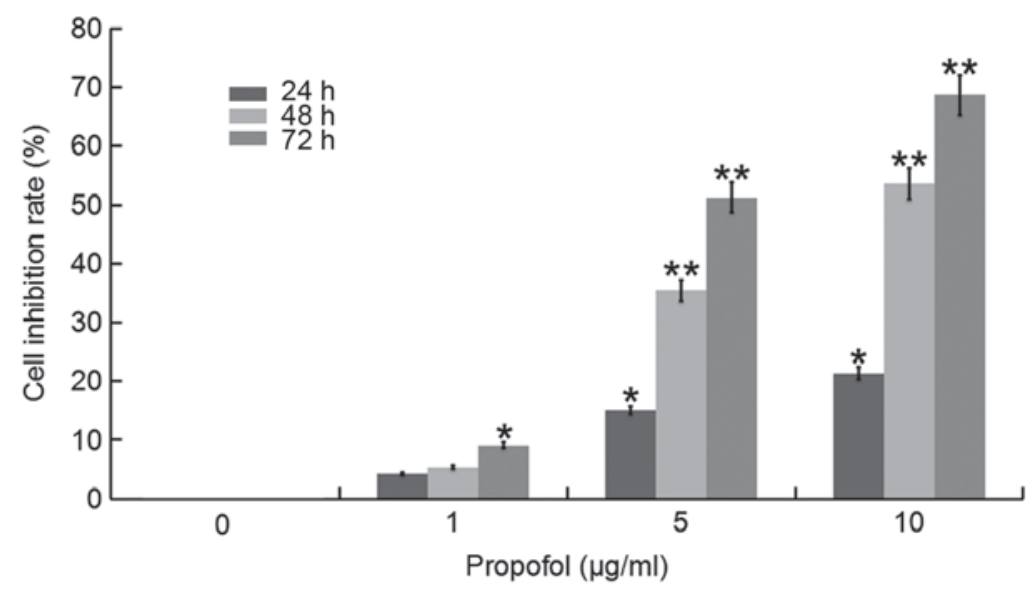

Figure 1. Effect of propofol on QBC939 cell proliferation. QBC939 cells were treated with different concentrations of propofol (0, 1,5 and $10 \mu$ g/ml) for 24,48 and $72 \mathrm{~h}$, respectively. Relative proliferation inhibition rate of cells was detected by MTT assay. Data are presented as the mean \pm standard deviation. ${ }^{*} \mathrm{P}<0.05,{ }^{* *} \mathrm{P}<0.01$ vs. $0 \mu \mathrm{g} / \mathrm{ml}$ propofol treatment group.

Propofol induces QBC939 cell apoptosis. To investigate whether propofol inhibited the proliferation of QBC939 cells via inducing apoptosis, flow cytometry was performed to detect cell apoptosis. Following treatment with various concentrations of propofol for $48 \mathrm{~h}$, the apoptosis rate of QBC939 cells appeared to increase as concentration of propofol increased (Fig. 3A and B). Furthermore, RT-qPCR and western blot analysis were conducted to determine the expression levels of apoptosis-associated genes, Bax and $\mathrm{Bcl}-2$. The results indicated that with an increase of propofol concentration, the Bax mRNA and protein level in QBC939 cells gradually increased, while the mRNA and protein level of Bcl-2 decreased (Fig. 3C-E).

Propofol induces cell-cycle arrest in QBC939 cells. To demonstrate the possible mechanism of propofol-induced cell growth inhibition in QBC939 cells, cell cycle progression was also analyzed. QBC939 cells were treated with different concentrations of propofol for $48 \mathrm{~h}$ and then the cell cycle distribution was analyzed using flow cytometry (data not shown). The results indicated that the percentage of G1 phase of QBC939 cells appeared to increase as concentration of propofol increased (Fig. 4A). In addition, the mRNA and protein expression of CyclinE, an important regulator of G1 and $\mathrm{S}$ phases in the cell cycle, was detected. It was identified that the expression of CyclinE was gradually decreased at the mRNA and protein level in QBC939 cells as propofol concentration increased compared with the control (Fig. 4B and C).

Propofol inhibits the Wnt/ $\beta$-catenin signaling pathway. QBC939 cells were treated with various concentrations of propofol for $48 \mathrm{~h}$, then the $\mathrm{Wnt} / \beta$-catenin signaling pathway was analyzed. RT-qPCR and western blot assays indicated that the expression of $\mathrm{Wnt} 3 \alpha, \beta$-catenin, Snaill and c-myc was gradually decreased at both the protein (Fig. 5A) and mRNA (Fig. 5B-E) level in QBC939 cells as propofol concentration increased compared with the control.

\section{Discussion}

CCA is a rapidly growing and lethal cancer that is usually incurable unless the primary tumor and any metastases are removed completely by surgery (22). As surgical treatment is prone to complications and seriously affects the quality of life of patients, in the postoperative period, it is necessary to strengthen the rehabilitation of patients with CCA from psychological and dietary perspectives $(23,24)$. Following CCA surgery, patients should follow their doctor's advice and 

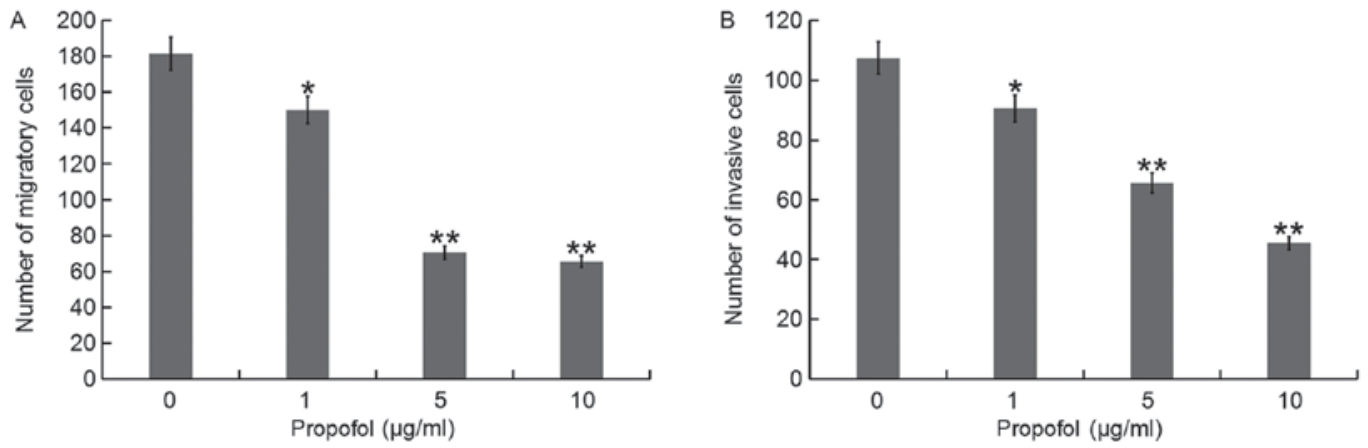

Figure 2. Effect of propofol on QBC939 cell migration and invasion capacity. QBC939 cells were treated with different concentrations of propofol (0, 1, 5 and $10 \mu \mathrm{g} / \mathrm{ml}$ ) for $48 \mathrm{~h}$. The migration and invasion of cells in different groups was determined by Transwell assay. The number of (A) migratory and (B) invasive cells was determined in triplicate. Data are presented as the mean \pm standard deviation. ${ }^{*} \mathrm{P}<0.05,{ }^{* *} \mathrm{P}<0.01 \mathrm{vs} .0 \mu \mathrm{g} / \mathrm{ml}$ propofol treatment group.

A Propofol $(\mu \mathrm{g} / \mathrm{ml})$

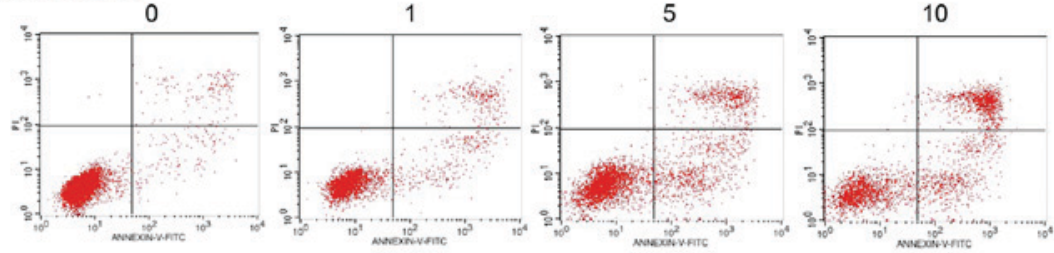

B

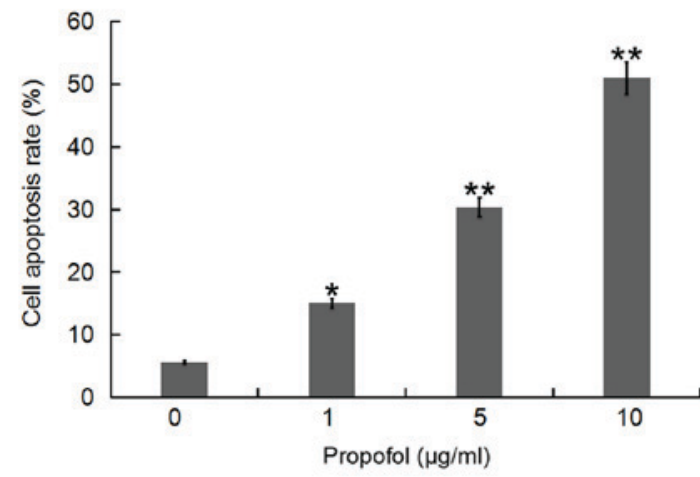

C

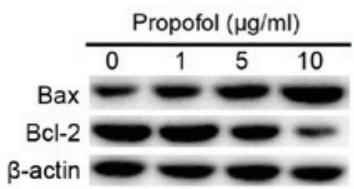

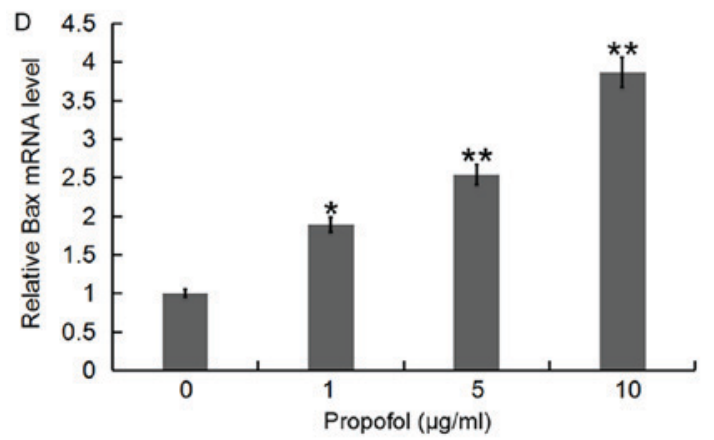

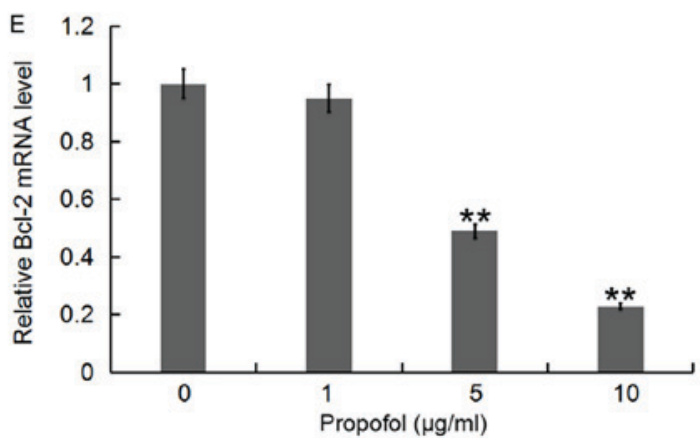

Figure 3. Effect of propofol on QBC939 cell apoptosis. QBC939 cells were treated with various concentrations of propofol $(0,1,5 \mathrm{and} 10 \mu \mathrm{g} / \mathrm{ml})$ for $48 \mathrm{~h}$. (A and B) QBC939 cell apoptosis was measured by flow cytometry and data were analyzed. (C) A western blot assay detected the protein expression levels of Bcl-2 and Bax. (D and E) An RT-qPCR assay detected the mRNA expression levels of (D) Bax and (E) Bcl-2. Data are presented as the mean \pm standard deviation. ${ }^{*} \mathrm{P}<0.05,{ }^{* *} \mathrm{P}<0.01$ vs. $0 \mu \mathrm{g} / \mathrm{ml}$ propofol treatment group.

regularly attend check-ups at their hospital, participate in light physical activity and avoid prolonged periods of sitting or low activity to facilitate the recovery of body function (25). However, the majority of CCA patients are diagnosed at an advanced stage, when surgery is not possible (26). Therefore, CCA treatment is still a major clinical challenge, and exploring new and effective drugs and strategies for the treatment of CCA is of great clinical significance.
Propofol is one of many anesthetics and has been extensively studied. Previous studies have suggested that it has an anti-cancer effect in addition to its anesthetic effect. Research has demonstrated that propofol could inhibit cancer cell proliferation, migration and invasion, and thus exert anti-tumor function (27-30). Previous studies have identified that propofol could inhibit the development of numerous cancer types, including pancreatic (31), breast (32), colon (33), gastric (34) 

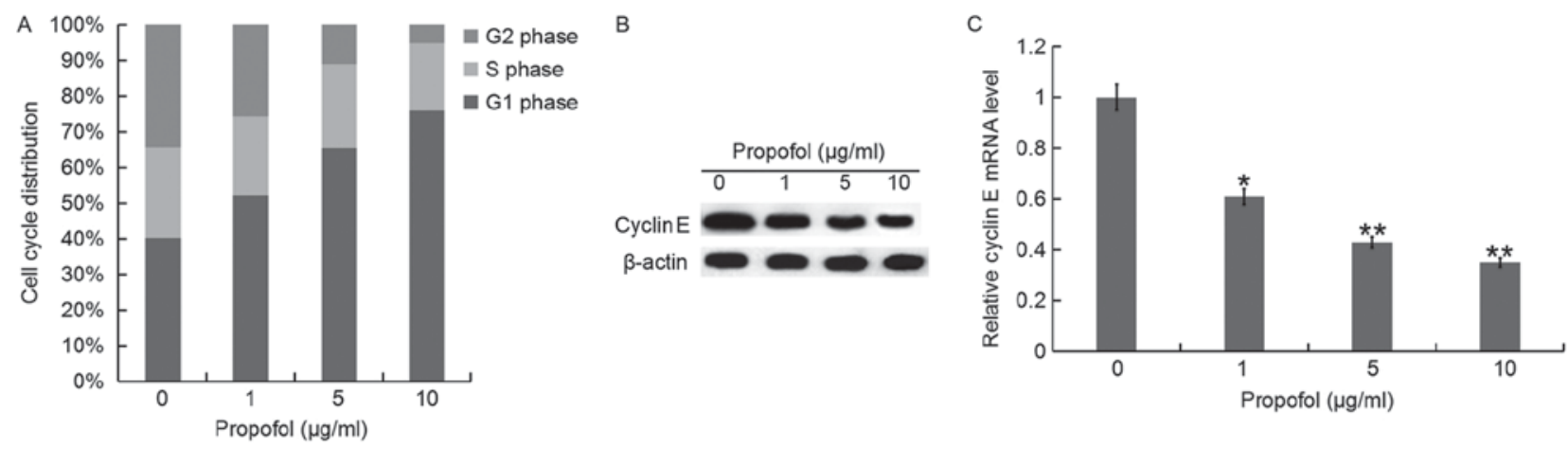

Figure 4. Effect of propofol on QBC939 cell cycle. QBC939 cells were treated with various concentrations of propofol $(0,1,5 \mathrm{and} 10 \mu \mathrm{g} / \mathrm{ml})$ for $48 \mathrm{~h}$. (A) QBC939 cell-cycle progression was examined by propidium iodide staining and flow cytometry. (B) A western blot assay detected the protein expression level of CyclinE. (C) An RT-qPCR assay detected the mRNA expression level of CyclinE. Data are presented as the mean \pm standard deviation. "P $<0.05$, ${ }^{* *} \mathrm{P}<0.01 \mathrm{vs.} 0 \mu \mathrm{g} / \mathrm{ml}$ propofol treatment group.
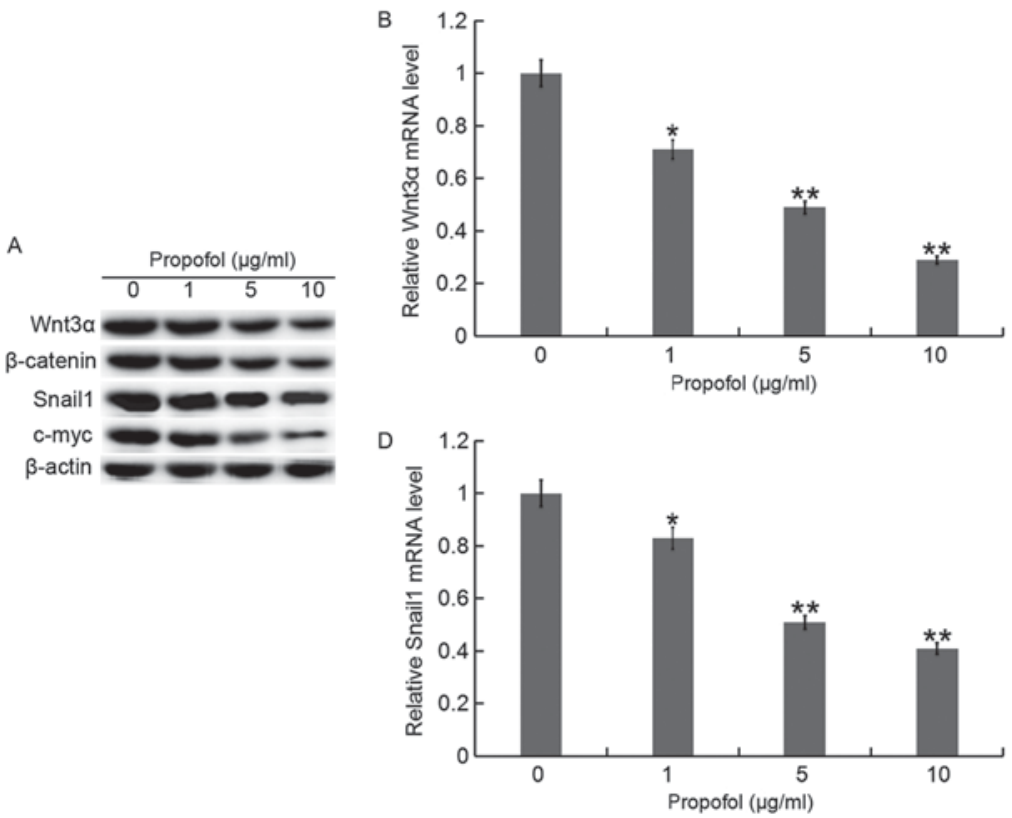
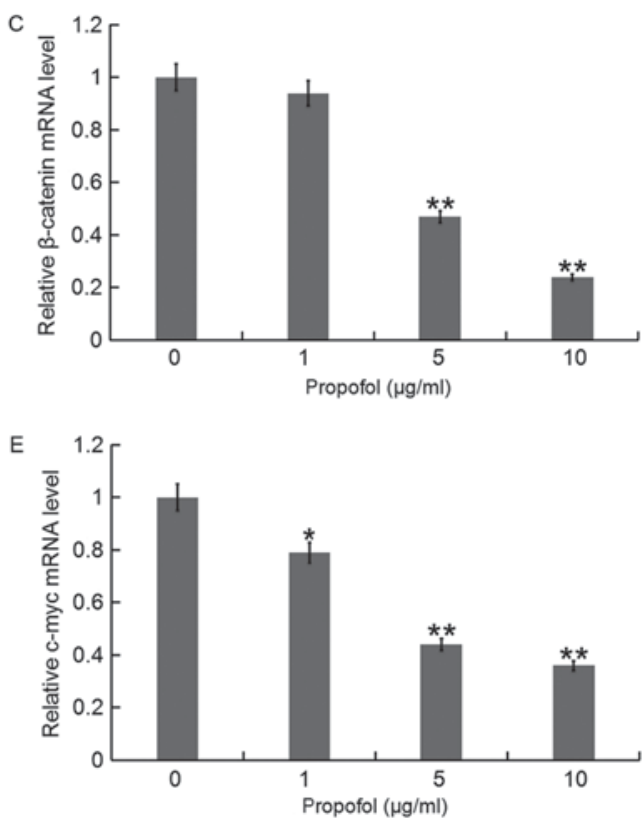

Figure 5. Effect of propofol on the Wnt/ $\beta$-catenin signaling pathway in QBC939 cells. QBC939 cells were treated with various concentrations of propofol $(0,1,5$ and $10 \mu \mathrm{g} / \mathrm{ml})$ for $48 \mathrm{~h}$. (A) A western blot assay measured the protein expression levels of Wnt $3 \alpha, \beta$-catenin, Snaill and c-myc. (B-E) An RT-qPCR assay was used to detect the mRNA levels of (B) Wnt $3 \alpha$, (C) $\beta$-catenin, (D) Snaill and (E) c-myc. Data are presented as the mean \pm standard deviation. "P $<0.05$, ${ }^{* * *} \mathrm{P}<0.01 \mathrm{vs} .0 \mu \mathrm{g} / \mathrm{ml}$ propofol treatment group.

and cervical (35) cancer. Zhang et al (36) demonstrated that propofol promotes the proliferation and invasion of gallbladder cancer cells by activating Nrf2. By contrast, Liu et al (37) indicated that propofol inhibits the proliferation and invasion of pancreatic cells by modulating the microRNA-21/Slug signaling pathway. However, there are few reports on the role of propofol in CCA, and the precise mechanism is still unknown. Therefore, the aim of the current study was to explore the effect of propofol on CCA QBC939 cells and its mechanism of action.

In the current study, an MTT assay demonstrated that as concentration of propofol and treatment time increased, the cell inhibition rate of QBC939 cells increased. Next, QBC939 cells were treated with different concentrations of propofol, and a Transwell assay was used to detect cell migration and invasion. Compared with the control group, experimental groups exhibited a significant decrease in the number of migratory and invasive cells. Therefore, these results indicated that propofol significantly inhibits the proliferation, invasion and migration of QBC939 cells, providing a theoretical basis for using propofol as a therapeutic drug for CCA.

Furthermore, flow cytometry was performed to analyze the apoptosis of QBC939 cells, and it was identified that the apoptosis rate of QBC939 cells appeared to increase as concentration of propofol increased. The effect of propofol on apoptosis-associated proteins in QBC939 cells was evaluated by RT-qPCR and western blot assays. The results suggested that propofol inhibited the expression of the anti-apoptotic protein $\mathrm{Bcl}-2$ and promoted the expression of the pro-apoptotic protein Bax. Another important finding in the current study was that propofol arrested cell cycle in the G1 phase, and it may be associated with a decrease in the protein level of CyclinE.

In recent decades, it has been reported that the Wnt/ $\beta$-catenin signaling pathway is closely associated with the 
occurrence of cancer. The Wnt/ $\beta$-catenin signaling pathway plays an important regulatory role in the proliferation, survival and metastasis of tumor cells $(38,39)$. To further explore the molecular mechanism of propofol-induced apoptosis in human CCA QBC939 cells, the effect of propofol on certain genes (Wnt $3 \alpha, \beta$-catenin, Snaill and c-myc) in the $\mathrm{Wnt} / \beta$-catenin signaling pathway was examined. It was identified that as the concentration of propofol increased, the expression of Wnt $3 \alpha, \beta$-catenin, Snaill and c-myc gradually decreased. In future experiments, the association between propofol and this pathway will be studied in greater detail.

In summary, the current results indicate that propofol inhibits the proliferation, migration and invasion of QBC939 cells, and induces apoptosis and cell cycle arrest. Its mechanism of action may be associated with the Wnt/ $\beta$-catenin signaling pathway. This could provide a target and experimental basis for clinical treatment of CCA. However, the current study is a preliminary study of the effects of propofol on CCA and more detailed research in this area is required. Future studies will aim to investigate the effects of propofol on other CCA cell lines and study the molecular mechanisms of propofol in depth.

\section{Acknowledgements}

Not applicable.

\section{Funding}

No funding was received.

\section{Availability of data and materials}

The analyzed data sets generated during the present study are available from the corresponding author on reasonable request.

\section{Authors' contributions}

ZZ collaborated to design the study. MZ and SW assessed and analyzed the data. All authors, including $\mathrm{CW}$, collaborated to interpret the results and develop the manuscript.

\section{Ethics approval and consent to participate}

Not applicable.

\section{Patient consent for publication}

Not applicable.

\section{Competing interests}

The authors declare that they have no competing interests.

\section{References}

1. Khan SA, Davidson BR, Goldin RD, Heaton N, Karani J, Pereira SP, Rosenberg WM, Tait P, Taylor-Robinson SD, Thillainayagam AV, et al: Guidelines for the diagnosis and treatment of cholangiocarcinoma: An update. Gut 61: 1657-1669, 2012.

2. Blechacz B and Gores GJ: Cholangiocarcinoma: Advances in pathogenesis, diagnosis, and treatment. Hepatology 48: 308-321, 2008.
3. Shaib YH, Davila JA, Mcglynn K and El-Serag HB: Rising incidence of intrahepatic cholangiocarcinoma in the United States: A true increase?. J Hepatol 40: 472-477, 2004.

4. Landis SH, Murray T, Bolden S and Wingo PA: Cancer statistics, 1998. Ca Cancer J Clin 48: 6-29, 2010.

5. Wang Q, Du T and Lu C: Perioperative blood transfusion and the clinical outcomes of patients undergoing cholangiocarcinoma surgery: A systematic review and meta-analysis. Eur J Gastroenterol Hepatol 28: 1233-1240, 2016.

6. Yuan D, Huang S, Berger E, Liu L, Gross N, Heinzmann F, Ringelhan M, Connor TO, Stadler M, Meister M' et al: Kupffer cell-derived Tnf triggers cholangiocellular tumorigenesis through JNK due to chronic mitochondrial dysfunction and ROS Cancer Cell 31: 771-789, 2017.

7. Rahnemai-Azar AA, Weisbrod AB, Dillhoff M, Schmidt C and Pawlik TM: Intrahepatic cholangiocarcinoma: Current management and emerging therapies. Expert Rev Gastroenterol Hepatol 11: 439-449, 2017.

8. Chen X, Wu Q, Sun P, Zhao Y, Zhu M and Miao C: Propofol disrupts aerobic glycolysis in colorectal cancer cells via inactivation of the NMDAR-CAMKII-ERK Pathway. Cell Physiol Biochem 46: 492-504, 2018.

9. Cockshott ID Briggs LP Douglas EJ and White M: Pharmacokinetics of propofol in female patients. Studies using single bolus injections. Br J Anaesth 59: 1103-1110, 1987.

10. Buckley A, McQuaid S, Johnson P and Buggy DJ: Effect of anaesthetic technique on the natural killer cell anti-tumour activity of serum from women undergoing breast cancer surgery: A pilot study. Br J Anaesth 113: 56-62, 2014.

11. Zhang T, Fan Y, Liu K and Wang Y: Effects of different general anaesthetic techniques on immune responses in patients undergoing surgery for tongue cancer. Anaesth Intensive Care 42: 220-227, 2014

12. Jaura AI, Flood G, Gallagher HC and Buggy DJ: Differential effects of serum from patients administered distinct anaesthetic techniques on apoptosis in breast cancer cells in vitro: A pilot study. Br J Anaesth 113: 63-67, 2014.

13. Ecimovic P, McHugh B, Murray D, Doran P and Buggy DJ: Effects of sevoflurane on breast cancer cell function in vitro. Anticancer Res 33: 4255-4260, 2013.

14. Kurosawa $S$ and Kato M: Anesthetics, immune cells, and immune responses. J Anesth 22: 263-277, 2008.

15. Siddiqui RA, Zerouga M, Wu M, Wu M, Castillo A, Harvey K, Zaloga GP and Stillwell W: Anticancer properties of propofol-docosahexaenoate and propofol-eicosapentaenoate on breast cancer cells. Breast Cancer Res 7: R645-R654, 2005

16. Wu KC, Yang ST, Hsia TC, Yang JS, Chiou SM, Lu CC, Wu RS and Chung JG: Suppression of cell invasion and migration by propofol are involved in down-regulating matrix metalloproteinase-2 and p38 MAPK signaling in A549 human lung adenocarcinoma epithelial cells. Anticancer Res 32: 4833-4842, 2012.

17. Qian J, Shen S, Chen W and Chen N: Propofol reversed Hypoxia-induced docetaxel resistance in prostate cancer cells by preventing epithelial-Mesenchymal transition by inhibiting hypoxia-Inducible factor $1 \alpha$. Biomed Res Int 2018: 4174232, 2018.

18. Li Q, Zhang L, Han Y, Jiang Z and Wang Q: Propofol reduces MMPs expression by inhibiting NF-kB activity in human MDA-MB-231 cells. Biomed Pharmacother 66: 52-56, 2012.

19. Meng C, Song L, Wang J, Li D, Liu Y and Cui X: Propofol induces proliferation partially via downregulation of $\mathrm{p} 53$ protein and promotes migration via activation of the Nrf2 pathway in human breast cancer cell line MDA-MB-231. Oncol Rep 37: 841-848, 2017.

20. Huang X, Teng Y, Yang $\mathrm{H}$ and Ma J: Propofol inhibits invasion and growth of ovarian cancer cells via regulating miR-9/NF- $\mathrm{B}$ signal. Braz J Med Biol Res 49: e5717, 2016.

21. Livak KJ and Schmittgen TD: Analysis of relative gene expression data using real-time quantitative PCR and the 2(-Delta Delta C(T)) method. Methods 25: 402-408, 2011.

22. Liu XF, Tang K, Sui LL and Xu G: Cholangiocarcinoma: Present status and molecular aspects of diagnosis. Onco Res 22: 177-183, 2014.

23. El Chafic AH, Dewitt J, Leblanc JK, El Hajj II, Cote G, House MG, Sherman S, McHenry L, Pitt HA, Johnson C, et al: Impact of preoperative endoscopic ultrasound-guided fine needle aspiration on postoperative recurrence and survival in cholangiocarcinoma patients. Endoscopy 45: 883-889, 2013.

24. Jeong S, Zheng B, Wang J, Chi J, Tong Y, Xia L, Xu N, Zhang J, Kong X, Gu J and Xia Q: Transarterial chemoembolization: A favorable postoperative management to improve prognosis of hepatitis B virus-associated intrahepatic cholangiocarcinoma after surgical resection. Int J Biol Sci 13: 1234-1241, 2017. 
25. Kovalenko YA, Vishnevsky VA, Chzhao AV and Zharikov YO: New criteria of radical surgery and long-term outcomes of hilar cholangiocarcinomamanagement (Russian). Khirurgiia (Mosk) 4-11, 2018.

26. Yao D, Kunam VK and Li X: A review of the clinical diagnosis and therapy of cholangiocarcinoma. J Int Med Res 42: 3-16, 2014

27. Deng F, Ouyang M, Wang X, Yao X, Chen Y, Tao T, Sun X, Xu L, Tang J and Zhao L: Differential role of intravenous anesthetics in colorectal cancer progression: Implications for clinical application. Oncotarget 7: 77087-77095, 2016.

28. Ecimovic P, Murray D, Doran P and Buggy DJ: Propofol and bupivacaine in breast cancer cell function in vitro-role of the NET1 gene. Anticancer Res 34: 1321-1331, 2014.

29. Peng $Z$ and Zhang Y: Propofol inhibits proliferation and accelerates apoptosis of human gastric cancer cells by regulation of microRNA-451 and MMP-2 expression. Genet Mol Res 15: 2016.

30. Mammoto T, Mukai M, Mammoto A, Yamanaka Y, Hayashi Y, Mashimo T, Kishi Y and Nakamura H: Intravenous anaesthetic, propofol inhibits invasion of cancer cells. Cancer Lett 184: 165-170, 2002

31. Chen X, Wu Q, You L, Chen S, Zhu M and Miao C: Propofol attenuates pancreatic cancer malignant potential via inhibition of NMDA receptor. Eur J Pharmacol 795: 150-159, 2017.

32. Chen X, Lu P, Chen L, Yang SJ, Shen HY, Yu DD, Zhang XH, Zhong SL, Zhao JH and Tang JH: Perioperative propofol-paravertebral anesthesia decreases the metastasis and progression of breast cancer. Tumour Biol 36: 8259-8266, 2015.
33. Xu YJ, Li SY, Cheng Q, Chen WK, Wang SL, Ren Y and Miao CH: Effects of anaesthesia on proliferation, invasion and apoptosis of LoVo colon cancer cells in vitro. Anaesthesia 71: 147-154, 2016.

34. Wang ZT, Gong hY, Zheng F, Liu DJ and Yue XQ: Propofol suppresses proliferation and invasion of gastric cancer cells via downregulation of microRNA-221 expression. Genet Mol Res 14: 8117-8124, 2015.

35. Zhang D, Zhou XH, Zhang J, Zhou YX, Ying J, Wu GQ and Qian JH: Propofol promotes cell apoptosis via inhibiting HOTAIR mediated mTOR pathway in cervical cancer. Biochem Biophys Res Commun 468: 561-567, 2015.

36. Zhang L, Wang N, Zhou S, Ye W, Jing G and Zshang M: Propofol induces proliferation and invasion of gallbladder cancer cells through activation of Nrf2. J Exp Clin Cancer Res 31: 66, 2012.

37. Liu Z, Zhang J, Hong G, Quan J, Zhang L and Yu M: Propofol inhibits growth and invasion of pancreatic cancer cells through regulation of the miR-21/Slug signaling pathway. Am J Transl Res 8: 4120-4133, 2016.

38. Guo Q, Shen S, Liao M, Lian P and Wang X: NGX6 inhibits cell invasion and adhesion through suppression of Wnt $/ \beta$-catenin signal pathway in colon cancer. Acta Biochim Biophys Sin (Shanghai) 42: 450-456, 2010.

39. Mohammed MK, Shao C, Wang J, Wei Q, Wang X, Collier Z, Tang S, Liu H, Zhang F, Huang J, et al: Wnt $/ \beta$-catenin signaling plays an ever-expanding role in stem cell self-renewal, tumorigenesis and cancer chemoresistance. Genes Dis 3: 11-40, 2016. 